\title{
ETHNOOCEANOGRAPHY DAN TITIK TEMU ASPEK SYAR'I DALAM PENENTUAN AWAL BULAN RAMADHAN DAN SYAWAL OLEH JOGURU KESULTANAN TIDORE
}

\author{
Salnuddin, I Wayan Nurjaya, Indra Jaya, Nyoman M.N. Natih \\ Program Studi Ilmu Kelautan, FPIK - Universitas Khairun, Ternate \\ Departemen Ilmu dan Teknologi Kelautan, FPIK - IPB, Bogor \\ e-mail: sal_unkhair@yahoo.co.id
}

\begin{abstract}
Ethnooceanography and the intersection of shar'i aspects to determination of the early of Ramadan and Shawwal by Joguru Sultanate of Tidore. The determination of the early of the new month of Ramadan and Shawwal was very important for Muslims because it is related to the time of worship. Judge syara 'The Sultanate of Tidore (Joguru) has long applied the method of determining the early month of Hijri (Ramadan and Shawwal) through tidal movement observed on "akebai" included in ethooceanography and called Joguru Method (M)). Hilal that has never been seen in Tidore and its surrounding areas in the long-term cycle of moon (34 years) caused its early moon to be inapplicable due to non-fulfillment of the requirement of hisab (hadith). MJ makes observation (rukyat) change of tidal movement on "akebai" is "ijtihād". The appropriateness of the scientific aspects of ethnoocaenography and the intersection of the shar'i aspects make it a comparative method of determining the beginning of the new month of Hijri in astronomy (hilāl). Required the expansion of the meaning of the "hilāl" as an indicator of the beginning of the month of the Hijri calendar.
\end{abstract}

Ethnooceanography dan titik temu aspek Syar'i dalam penentuan awal bulan Ramadhan dan Syawal oleh Joguru Kesultanan Tidore. Penentuan awal bulan baru Ramadhan dan Syawal sangat penting bagi umat Islam karena berkaitan dengan waktu ibadah. Hakim syara' Kesultanan Tidore (Joguru) telah lama mengaplikasikan metode penentuan awal bulan baru Hijriah (Ramadhan dan Syawal) melalui pergerakan pasang surut yang terpantau pada "akebai" termasuk dalam ethooceanography dan disebut dengan Metode Joguru (M)). Hilal yang tidak pernah terlihat di wilayah Tidore dan sekitarnya selama siklus jangka panjang (34 tahun) menyebabkan hisab awal bulan tidak dapat diaplikasikan akibat tidak terpenuhinya persyaratan hisab (hadis). MJ melakukan pengamatan (rukyat) perubahan tinggi air pada "akebai" adalah "ijtihad". Terdapat kesesuaian aspek sains dari ethnoocaenography serta titik temu aspek syar'i yang menjadikan MJ berpotensi sebagai metode utama sekaligus sebagai metode pembanding dari metode umum dalam penentuan awal bulan baru Hijriah. Diperlukan perluasan makna kata "hilal" sebagai indikator awal bulan baru penanggalan Hijriah.

Keywords: Joguru, Akebai, ethooceanography, hadīth; ijtihād 


\section{Pendahuluan}

Ketampakan Hilal (first new cresent) merupakan fenomena alam yang sangat penting bagi seluruh umat Islam karena sebagai penentu awal masuknya penanggalan Islam (penanggalan Hijriah) serta berkaitan dengan waktu ibadah seperti puasa Ramadhan, Shalat Ied dan haji1. Penanggalan Hijriah disusun berdasarkan pergerakan Bulan (lunar calender) dimana hilal merupakan kajian astronomi yang sangat disyaratkan ketampakannya di suatu wilayah dan sebagai keputusan final masuknya bulan baru Hijriah (Ramadhan dan Syawal). Persoalan yang cenderung menyulut perdebatan, jika perhitungan awal bulan baru Hijriah (hisab) telah dipublikasikan oleh para ormas Islam sebelum pengamatan hilal (ru'yat al-hilāl) dilakukan. Persoalan akan menjadi lebih rumit, jika hilal tidak terlihat, baik akibat posisi Bulan dan Matahari yang tidak memungkinkan untuk melihatnya maupun akibat gangguan cuaca² ${ }^{2}$ engan merujuk pada imkān al-ru'yat.

Perkembangan Ilmu Astronomi (Falak) di Indonesia cukup meningkat pesat, dimana banyak berdiri program pendidikan dengan kurikulum ilmu falak di lembaga pendidikan tinggi Islam dan pesantren. Selain itu banyak pula berdiri lembaga ilmu falak yang berasal dari Ormas Islam maupun dari kelompok masyarakat profesi, serta dari individu pencinta atau penggemar Ilmu Falak. Secara umum, lembaga-lembaga tersebut dominan masih menggunakan pendekatan astronomi dengan metode klasik dan kajian masih bersifat teoritis-filosofis ${ }^{3}$. Lebih lanjut, Kementerian Agama RI ${ }^{4}$ telah mencatat

\footnotetext{
${ }^{1}$ S. Anwar, "Perkembangan Pemikiran tentang Kalender Islam Internasional", di dalam: Musyawarah Ahli Hisab dan Fikih Muhammadiyah, Yogyakarta. 21-22 Jumadis Saniah 1429 H / 25-26 Juni 2008.; 2008, Yogyakarta. Lihat juga M. Nashirudin, "Tinjauan Fikih dan Astronomis Penyatuan Matlak;" dalam Ijtihad. Jurnal Wacana Hukum Islam dan Kemanusiaan, 2012, 12(2), h. 179 - 192. S. Azhari, "Penyatuan Kalender Islam: Mendialogkan Wujūd al-Hilāl dan Visibilitas Hilal," dalam Jurnal Ahkam, Vol. XIII No. 2,2013, h. 157-166.

${ }^{2}$ M. Salimi, "Visibilitas Hilal Minimum: Studi Komparatif antara Kriteria Depag RI dan Astronomi, 2005. T. Djamaluddin, Visibilitas Hilal di Indonesia," Warta LAPAN. 2, 2010, h. 4, DEPAG, Ilmu Falak Praktik, Jakarta:, Sub Direktorat Pembinaan Syari'ah dan Hisab Rukyat, Direktorat Urusan Agama Islam \& Pembinaan Syari'ah, Direktorat Jenderal Bimbingan Masyarakat Islam, Kementerian Agama Republik Indonesia. Cet. I, November 2013, 2013, h. 244, Lihat juga A. Izzuddin, "Dinamika Hisab Rukyat di Indonesia", dalam Istinbath Jurnal Hukum, Vol. 12, 2015, h. 2.

${ }^{3}$ S. Azhari, "Ilmu Falak: Perjumpaan Khazanah Islam dan Sains Modern", Suara Muhammadiyah, 2007, S. Jannah, "Urgensi Hisab dan Rukyat Pasca UU No. 3 Tahun 2006", dalam Jurnal Al-Mawarid
} 
metode hisab awal bulan dengan pendekatan astronomi (ephimeries) yang umumnya diaplikasikan oleh Ormas Islam di Indonesia, sedangkan Azhari5, menyebutkan terdapat 28 referensi dalam kajian ilmu falak tentang hilal berdasarkan pendekatan astronomi (ephimeries) yang berkembang di Indonesia dan Malaysia.

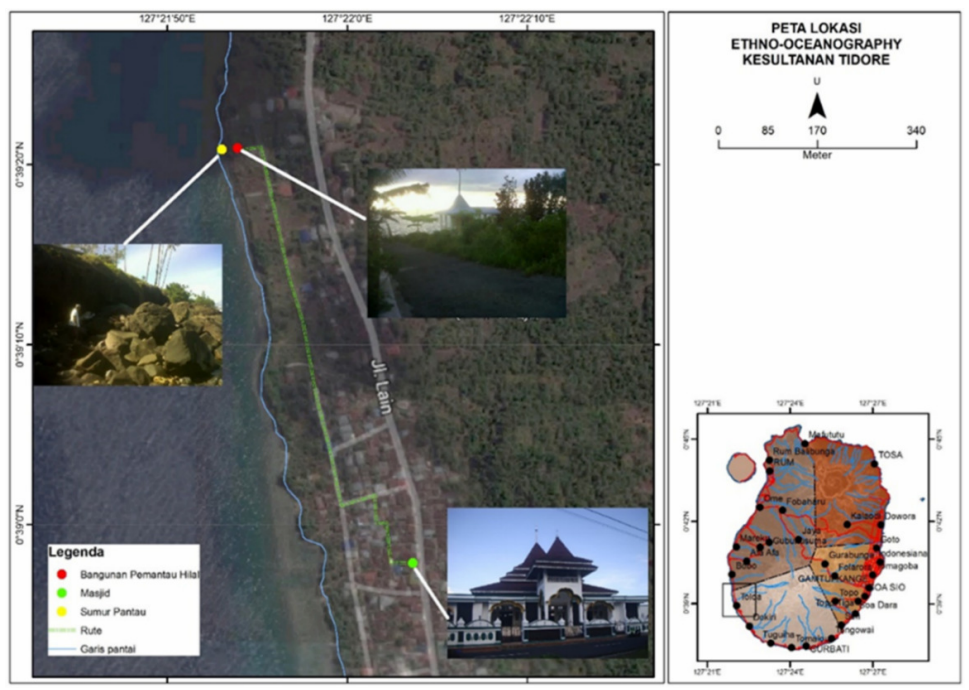

Gambar 1.

Lokasi pemantauan Akebai dengan Metode Joguru

Terkait dengan hal di atas, masyarakat Tidore yang tidak terpisahkan dengan kebesaran Kesultanan Tidore mempunyai pendekatan lain dalam menentukan awal bulan Ramadhan dan Syawal. Para imam masjid (Hakim Syara') yang biasa disebut dengan "Joguru" melakukan penentuan awal bulan Hijriah dengan mengamati pergerakan Matahari dan Bulan serta pergerakan air pada Akebai. ${ }^{6}$ Lokasi pemantauan berlokasi di Doelamo7 (Gambar 1). Cara

(Jurnal Hukum Islam), 2007, h. 17, lihat juga M. Maskufa, "Ilmu Falak: Relasi Harmonis Antara Agama dan Sains", dalam Jurnal Akademika, Vol. 18, 2013, h. 1.

4Kementerian Agama RI, Ilmu Falak Praktik, h. 244.

${ }^{5}$ S. Azhari, "Perkembangan Kajian Astronomi Islam di Alam Melayu”, dalam Journal of Fiqh, Vol. 7, 2010, h. 167-184.

${ }^{6}$ Akebai ; Bahasa Tidore (Ake = air, dan Bai = gali); Sumber air tawar yang terdapat di pantai, umumnya dibuat dalam bentuk sumur (kolam) untuk menampung air tawar. Posisi geografis Akebai pada $0^{\circ} 39^{\prime} 20.8^{\prime \prime} \mathrm{LU}$ dan $127^{\circ} 21^{\prime} 54^{\prime \prime} \mathrm{BT}$. 
Joguru tersebut selanjutnya saya sebut dengan Metode Joguru (MJ). Kata "Joguru" adalah sebutan bagi imam masjid Kesultanan Tidore, dimana kata Joguru secara umum bermakna "Mahaguru atau Tuan guru" untuk bidang keagamaan dan kebatinan. Kemampuan seorang Joguru sangat dihormati di kalangan masyarakat Tidore ${ }^{8}$ maupun masyarakat di Afrika Selatan ${ }^{9}$.

Metode Joguru tersebut sudah lama diaplikasikan, jauh sebelum pusat Kesultanan Tidore dipindahkan dari Kelurahan Toloa ke Kelurahan Soasio. Hal tersebut berdasarkan informasi Hi. Hasanuddin Malagapi ${ }^{10}$ yang mendengar dari cerita kakeknya (Joguru dari Gimalaha ${ }^{11}$ Banawa dan Tahisa) bahwa lokasi Akebai (Doelamo) telah menjadi lokasi pemantauan masuknya awal bulan Ramadhan dan Syawal sejak zaman Kesultanan Tidore, selanjutnya Gorotomolle, ${ }^{12}$ menjelaskan Doelamo sebagai lokasi tetap pemantaun hilal oleh pemerintah dan termuat dalam RT/RW Kota Tidore Kepulauan. Informasi tentang MJ diperkuat pula juga "JoJau" (Perdana Menteri) Kesultanan Tidore $^{13}$ bahwa kegiatan dan lokasi pemantauan dilakukan pada lokasi yang sama (Doelamo). Hal ini berarti MJ telah diaplikasikan lebih dari 800 tahun. ${ }^{14}$ Eksistensi Kesultanan Tidore terhadap MJ memerlukan kajian komprehensif guna_memahami pemikiran para Joguru di Kesultanan Tidore sebagai kajian

${ }^{7}$ Doelamo : Bahasa Tidore (doe = tanjung, dan lamo = besar); lokasi pemantauan awal bulan baru Hijriah dengan MJ yang berlokasi di Kelurahan Toloa Kec. Tidore Selatan - Kota Tidore Kepulauan Maluku Utara (Gambar 2) dengan posisi geografis $0^{\circ} 39^{\prime} 21^{\prime \prime} \mathrm{LU}$ dan $127^{\circ} 22^{\prime} 1,2^{\prime \prime} \mathrm{BT}$.

${ }^{8} \mathrm{~L}$. Probojo, "Ritual Guardians Versus Civil Servants as Cultural Brokers in the New Order Era: Local Islam in Tidore, North Maluku 1", dalam Indonesia and the Malay World, Vol. 38 No. 110, 2010, h. 95-107.

${ }^{9}$ B. Marasabessy, "Tuan Guru: The Cap Muslim Muslim Phylosophy Education System", dalam MAKARA of Social Sciences and Humanities, Series. 8, 2010, h. 3.

${ }^{10} \mathrm{Hi}$. Hasanuddin Malagapi (interview Juli 2014) memberikan informasi tentang tatacara Joguru melakukan pemantauan awal bulan baru Hijriah (Syawal dan Ramadhan) dan melihat untuk terakhir kalinya Joguru Imam Besar Abd. Rahim Fabanyo beserta dewan Syara' lainnya (9 orang) melakukan pemantauan awal bulan Ramadhan dan Syawal di tahun 1980-an.

${ }^{11}$ Bahasa Tidore ( $G i=$ Orang atau kelompok orang; Malaha = lurus dan "besar") adalah kelompok masyarakat yang merupakan bagian dari Kelembagaan Kesultanan Tidore (12 Gimalaha), mereka mempunyai hak mengusulkan calon Sultan di Kesultanan Tidore.

${ }^{12}$ Hasan Gorotomole, Kepala Kelurahan Toloa, Interview, 2 Juli 2014.

${ }^{13}$ Hi. Masmin Faroek. (Diskusi Maret 2016).

${ }^{14}$ Merujuk waktu perebutan Benteng Kesultanan Tidore oleh Sultan Nuku sekaligus sebagai hari jadi Tidore, bulan April 2017, Tidore sudah memasuki usia 988 tahun . 
kesesuaian aspek Syar'i15 dan sains dalam penentuan awal bulan Hijriah terutama Ramadhan dan Syawal.

\section{Dasar Penggunaan Metode Joguru}

Hilal umumnya diartikan sebagai ketampakan Bulan sabit tipis (first new cresent), secara geometrik hilal dapat diartikan sebagai proyeksi cahaya Matahari yang sampai ke Bulan akibat terhalang oleh Bumi dan terlihat di Bumi. Awal bulan Hijriah sendiri ditandai dengan peristiwa Ijtimak yaitu posisi Bulan dan Matahari searah dilihat dari Bumi, dimana potensi hilal akan terlihat setelah periode 23 jam (maksimum) setelah ijtimak ${ }^{16}$ dan posisi hilal cukup tinggi. Hilal dapat terlihat jika setelah Matahari terbenam dan Bulan telah terbit ${ }^{17}$ (moonset) yang selanjutnya waktu tersebut menyebabkan variasi tinggi Bulan (imkān al-ru'yat) di tiap wilayah pemantauan hilal senantiasa berbeda.

Untuk mengetahui potensi terlihatnya hilal awal bulan Ramadhan dan Syawal di wilayah Tidore dan sekitarnya, dilakukan perhitungan waktu tenggelamnya Matahari atau mereka menyebutnya dengan istilah "wange soru"18 (sunset) dan terbitnya Bulan dengan istilah "ora fane"19 (moonset). Perhitungan sunset dan moonset menggunakan Software Accurate Time ver

\footnotetext{
${ }^{15}$ Baca T. Djamaluddin, "Faktor Penting dalam Penentuan Kriteria Hisab Rukyat (Handout)", dalam Prosiding Seminar Nasional Hilal, Lembang - Jawa Barat-19 Desember 2009/2 Muharram 1431 H, Kelompok Keilmuan Astronomi dan Observatorium Bosscha, FMIPA-ITB, Observatorium Bosscha, FMIPA-ITB, 2009, h. 27-30.

16T. Djamaluddin, Interview, 9 Agustus 2016 di Kantor Lapan.

${ }^{17}$ Ora fane (bahasa Tidore; ora = Bulan, fane =bergerak naik/muncul/terbit), Lihat uraian pada footnote No.19.

${ }_{18}$ Wange soru (bahasa Tidore; wange $=$ Matahari dan soru $=$ masuk/celup/turun) Kata soru, mengambil makna dari aktifitas pandai besi yang mencelupkan besi panas (warna kemerahan) ke dalam air hingga warna merah menghilang/pudar. Proses tersebut bermakna sama dengan makin menghilangnya warna merah lembayun diufuk barat saat matahari terbenam (soru).

${ }^{19}$ Ora fane (bahasa Tidore; ora = Bulan, fane =bergerak naik/muncul/terbit), yaitu istilah yang menjelaskan fenomena alam dari mulai muncul/nampaknya bulan sabit di awal bulan baru Hijriah (bulan bercahaya) atau waktu bulan menampakkan cahayanya pertama kali yang waktunya sebelum shalat Isya; ora fane berada pada umur bulan muda (fase bulan baru ke fase kuartil I) yang dalam Bahasa Tidore disebut dengan "ora kiau". Bulan tenggelam bagi masyarakat Tidore adalah waktu dimana bulan tidak nampak lagi untuk waktu diakhir bulan Hijriah (umur bulan di atas 27 hari) yang disebut dengan "ora red" (rea = tidak ada). Dari hal tersebut, maka peristiwa Ora fane dengan sendirinya bermakna sama dengan waktu tenggelamnya bulan (moonset).
} 
5.3.720 yang hasil perhitungan memperlihatkan bahwa Matahari lebih awal tenggelam (notasi S) dibandingkan dengan Bulan (notasi M) atau konjungsi terjadi setelah shalat Maghrib (red line) pada Gambar 2) yang merujuk pada penanggalan yang dikeluarkan LFNU.21 Kisaran waktu Bulan terbit (moonset) untuk hari H-2 hingga H+2 berada pada jam 18: 21 - 21: 41 LT (Lokal Time) sedangkan waktu terbenamnya Matahari terjadi pada jam 18:33 WIT. Selisih waktu terbesar sunset dan moonset di hari H-1 (red line) pada tahun $1410 \mathrm{H} \mathrm{(1}$ jam 15 menit) dan selisih terendah pada tahun $1411 \mathrm{H}$ dan $1415 \mathrm{H}$ sebesar 22 menit (shape lingkaran). Waktu sunset dan moonset, menunjukkan bahwa pada wilayah Pulau Tidore sekitarnya tidak memungkinkan untuk melihat Hilal disepanjang tahun, hal tersebut juga diperlihatkan pada hasil simulasi tim ITB $^{22}$ dan juga informasi dari Joguru Fabanyo. ${ }^{23}$ Kader Fabanyo, S.Pd ${ }^{24}$ maupun beberapa laporan/berita resmi (News) dari web Kanwil Departemen Agama Propinsi di Indonesia Timur (Papua, Papua Barat, Maluku, Maluku Utara, Sulawesi Utara dan Gorontalo).

Hilal awal bulan Ramadhan dan Syawal yang tidak pernah terlihat sepanjang tahun (34 tahun ${ }^{25}$ ) di wilayah Tidore dan Sekitarnya, merupakan dasar utama Joguru Kesultanan Tidore menerapkan metode lain selain metode umum kita pahami. Lebih lanjut, dengan waktu_sunset dan moonset terhadap penentuan waktu terbaik pemantauan hilal atau best-time (TB26) menurut

20M. Odeh, Accurate Times 5.3.6 Software, Islamic Crescents' Observation Project (ICOP), 2013.

${ }^{21}$ Lihat, Kalender Masehi - Hijriah 1901 - 2100. Lajnah Falakiyah Nahdlatul Ulama. LFNU. Gresik, http://www.must4in.net/2013/12/kalender-Masehi-hijriyah-1901-2100.html, [Diunduh 15 April 2014].

${ }^{22}$ Lihat simulasi hilal di 9 lokasi kerjasama ITB dan berbagai lembaga pada http://bosscha. itb.ac.id/hilal/images/document/Ramadhan_1430H.pdf. [Diunduh 12 Maret 2014].

${ }^{23} \mathrm{Hi}$ Habibuddin Fabanyo, Joguru dan Imam besar Masjid Baitul Makmur Kelurahan Toloa, menyatakan bahwa saat pemerintah pusat menentukan awal bulan Ramadhan dan Syawal (Isbat) bulan sabit belum terlihat di Tidore, dan hilal terlihat pada hari ketiga sebelum Shalat Isya (Interview Agustus 2014).

${ }^{24}$ Kader Fabanyo, S.Pd, Staf Kandepag Kota Tidore Kepulauan, menyampaikan informasi dari seorang petugas Rukyatul Hilal Kota Tidore Kepulauan, yang mengatakan dalam 10 tahun terakhir petugas pemantau Hilal tidak pernah melihat Hilal awal bulan Ramadhan dan Syawal. (Interview Januari 2015 Via Telpon seluler).

${ }^{25}$ Siklus pergerakan bulan kembali pada posisi awalnya memerlukan waktu selama 33,3 tahun.

${ }^{26}$ Waktu terbaik dihitung dengan persamaan $\mathrm{Tb}=\mathrm{Ts}+(4 / 9) \mathrm{x}$ (Lag), dimana $\mathrm{Tb}=$ Best Time (Waktu terbaik untuk mengobservasi hilal, meru'yah); Ts = Waktu terbenam matahari (sunset) dan Lag = Moon's lag time, selisih waktu terbenamnya bulan dan matahari. 
Yallop27 terjadi pada malam hari saat H-1 (Gambar 3). Kondisi tersebut berarti, di Wilayah Tidrore dan sekitaranya tidak memungkinkan menyaksikan hilal diakibatkan TB untuk menyaksikan hilal terjadi selepas Shalat Maghrib (Matahari telah terbenam) dan saat itu posisi Bulan masih rendah (di bawah ufuk). Waktu TB tersebut menyebabkan Bulan akan terlihat di Tidore dan sekitarnya setelah hari ketiga bulan Hijriah. ${ }^{28}$
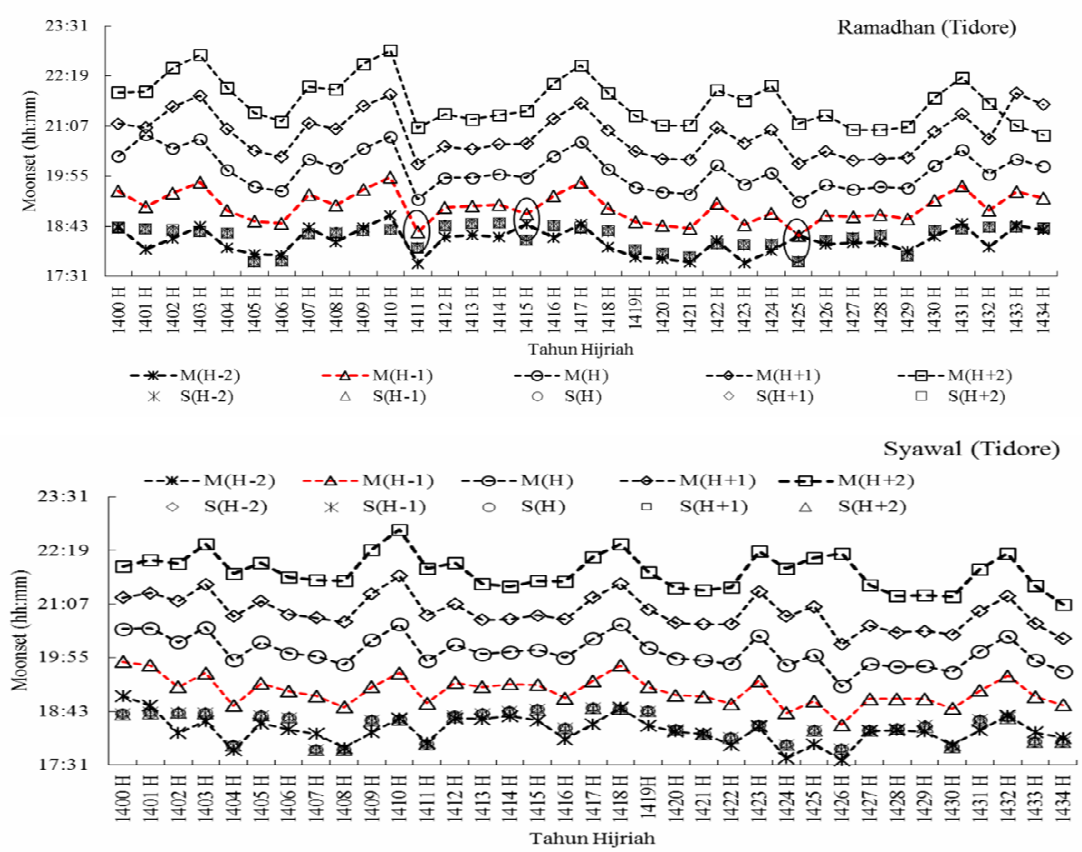

Keterangan::

$\mathrm{H}$ tanggal 1 bulan hijriah merujuk pada kalender yang dikeluarkan oleh LFNU dan tanda minus (-) dan plus (+) menunjukkan jumlah hari sebelum dan sesudah.

\section{Gambar 2 \\ Variasi waktu terbenamnya Matahari (sunset) dan terbitnya Bulan (moonset) di wilayah Tidore dan sekitarmya}

${ }^{27} B D$. Yallop, "A Method for Predicting the First Sighting of the New Crescent Moon", dalam NAO Technical Note, 1997, h. 69.

28Sesuai dengan informasi Hi. Habibuddin Fabanyo pada footnote No. 23. 

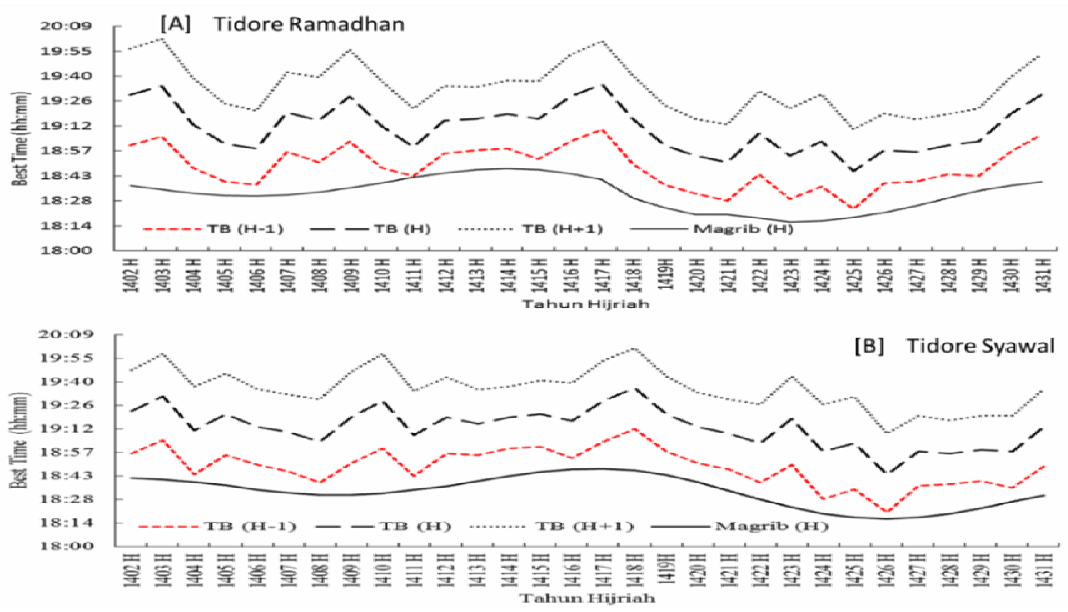

Gambar 3.

Waktu terbaik pemantauan Hilal terhadap waktu shalat Magrib untuk wilayah Tidore [A] dan [B]

\section{Tahapan Metode Joguru}

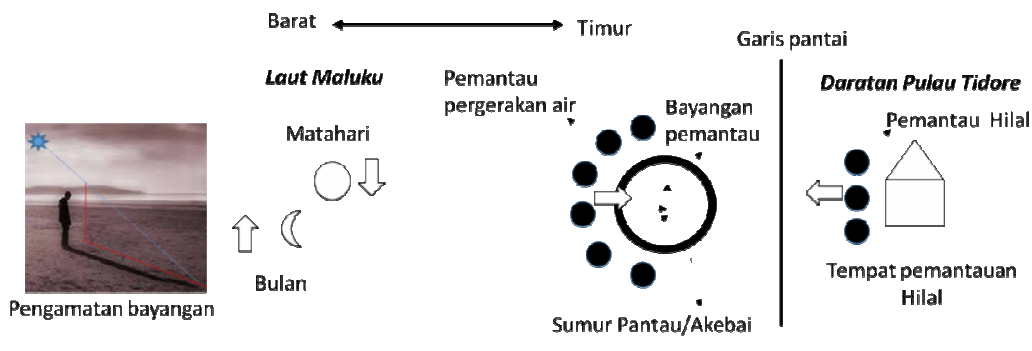

\section{Gambar 4.}

\section{Illustrasi teknik pemantauan awal bulan Ramadhan dan Syawal} dengan Metode Joguru

Joguru dan hakim syara' yang berjumlah 9 orang melakukan pemantauan awal bulan baru Ramadhan dan Syawal setelah mereka melakukan shalat fardhu Ashar, mereka berjalan kaki selama 30 menit $( \pm 1 \mathrm{~km})$ ke Doelamo (lihat Gambar 1) dan telah melakukan perhitungan sebelumnya untuk menentukan waktu pemantauan (hari dan jam). Pemantauan dilakukan dengan membagi dua kelompok joguru, kelompok pemantau hilal berdiri menghadap laut (barat) sambil mengamati pergerakan Matahari, sedangkan kelompok 
lainnya menghadap ke darat (timur) dengan membentuk lingkaran sambil mengamati pergeseran panjang bayangan mereka dan pergerakan tinggi air di "akebai" (Gambar 4).

Waktu pemantauan dengan MJ ditentukan berdasarkan perhitungan (hisab) dengan mekanisme penentuannya diperlihatkan pada Gambar 6. Waktu pemantauan (hari dan jam) bulan Ramadhan merujuk pada tinggi Bulan (sudut) saat Nishfu Sya'ban (15 hari bulan Sya'ban) yang mereka menyebutnya "ora talu"29, sedangkan untuk penentuan waktu pemantauan awal bulan Syawal ditentukan pula oleh tinggi Bulan (sudut) saat Nuzulul Quran (15 Ramadhan). Pada hari yang ditentukan untuk pemantauan (H-1), semua hakim syara' melakukan Shalat Ashar berjamaah, setelah itu bersama-sama menuju lokasi pemantauan (Doelamo). Indikator yang Joguru amati adalah panjang bayangan yang memotong lingkaran akebai dan pergerakan tinggi air pada "akebai". Pengamatan dihentikan saat terjadi pergerakan air bergerak naik (pasang) yang teramati tanpa menunggu ketampakan Bulan sabit tipis/ hilal (Gambar 5).
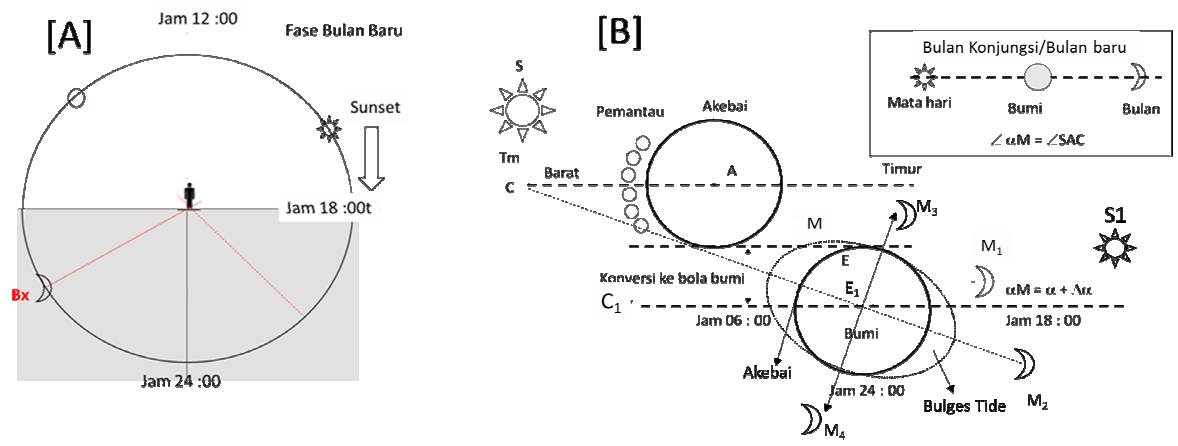

Gambar 5.

Illustrasi penentuan kondisi konjungsi (fase bulan baru) dari Metode Joguru terhadap indikator hilal pada Akebai

\footnotetext{
${ }^{29}$ Ora Talu (bahasa Tidore; ora = Bulan dan talu = umur bulan 15 menuju ke 16) ; merupakan waktu setelah puncak fase purnama (ora tuga) yang menjadi waktu referensi dalam menentukan hari dan jam pemantauan MJ yang dijelaskan pada Gambar 6.
} 
Waktu pemantauan setelah shalat Ashar, dengan mengasumsikan kondisi saat itu pada posisi Bulan baru maka posisi Matahari-Bumi-Bulan berada pada posisi $\mathrm{Bx}$ (Gambar $5 \mathrm{~A}$ ) atau pada garis $\mathrm{CE}_{1} \mathrm{M}_{2}$ dan di akebai sendiri pada garis SAM (Gambar 5B). Pada saat konjungsi maka terjadi pasang maksimum (bulges tide) dimana akebai berada pada garis $\mathrm{cE}_{1} \mathrm{M}_{2}$. Mempertimbangkan pemantauan oleh para Joguru, maka posisi Matahari berada pada posisi di $\mathrm{S}$ atau S1 (setelah Shalat Ashar) dan dalam kondisi surut ${ }^{30}$. Kondisi surut akan dijumpai saat Bulan berada pada posisi di $\mathrm{M}_{3}$ ( 6 jam sebelum konjungsi) atau Bulan berada di posisi $\mathrm{M}_{4}$ ( 6 jam setelah konjungsi) untuk lokasi pemantauan dengan tipe pasang surut diurnal. Berdasarkan tipe pasang surut yang berkembang di wilayah Indonesia timur didominasi oleh tipe semi diurnal ${ }^{31}$, maka perubahan pasang surut terjadi dalam interval waktu 3 jam. Periode bangkitan pasang surut dengan tipe pasut semi diurnal, maka posisi Bulan berada pada posisi $\mathrm{M}_{1}$, dimana posisi Bumi membentuk garis $\mathrm{E}_{1} \mathrm{M}_{1} \mathrm{~S} 1$ adalah kondisi ijtimak.

\section{Hisab Waktu Pemantauan Awal Bulan Hijriah dengan Metode Joguru}

Setiap awal bulan baru Hijriah (tanggal 1) mempunyai hari yang sama dengan hari di fase bulan purnama (tanggal 15 bulan Hijriah). Merujuk pada hisab urfi, jumlah dari dalam bulan Hijriah maka hari pada akhir bulan Hijriah (29 hari) jatuh pada keesokan harinya (+ 1 hari) atau hari kedua dari hari awal bulan Hijriah tersebut untuk jumlah hari selama 30 hari. ${ }^{32}$ Penentuan jam pemantauan dilakukan dengan mekanisme menentukan sudut Bulan $(\alpha)$ yang terbentuk dari pemantau di jam tertentu (Gambar 6A) dan dalam illustrasi menggunakan waktu pengukuran di jam 24:00 LT dengan posisi Bulan di $\mathrm{B}_{1}$ (ora talu). Pengamatan sudut Bulan dapat juga dilakukan merujuk waktu

\footnotetext{
${ }^{30}$ Ibid 3, memberikan informasi bahwa saat pemantauan Joguru tidak basah atau dengan makna bahwa kondisi saat pemantauan dalam keadaan surut. Hal tersebut juga diperkuat oleh kondisi lapangan bahwa saat pasang akebai akan tergenang oleh air laut (lihat gambar 1) sehingga dapat dipastikan bahwa akebai akan terlihat dan dapat dilakukan pemantauan (gambar 4) jika kondisi air dalam keadaan surut.

${ }^{31}$ Terjadi 2 kali pasang dan 2 kali surut dalam satu hari. Lihat BT. Widyantoro, "Karakteristik Pasang Surut Laut di Indonesia", dalam Jurnal Ilmiah Geomatika, Vol. 20 No. 1, 2014, h. 65-72.

32Ibid, h. 13.
} 
shalat maupun jam Matahari, dimana sudut Bulan $\left(\alpha_{1}\right)$ diterjemahkan sebagai ukuran panjang bayangan pemantau. Posisi Bulan pada B1 diproyeksikan posisinya sejauh $180^{\circ}$ untuk 14 -15 hari kemudian (awal Bulan baru Hijriah) dari fase purnama ke fase bulan baru yang menghasilkan posisi Bulan di $\mathrm{B}_{2}$ (Gambar 6B). Proyeksi tersebut menghasilkan posisi baru dengan keterlambatan Bulan minimal 21 menit (5,350) dari posisi awal proyeksi (B2), keterlambatan Bulan menyebabkan Bulan berada pada posisi $\mathrm{B}_{3}$ saat fase bulan baru. Keterlambatan tersebut akibat deviasi hari Bulan terhadap Matahari (sinodic Bulan) terhadap Bumi sebesar 44 menit 3 detik perbulan (1,5 menit/hari), sehingga dalam pergerakan menuju awal bulan baru (14 atau 15 hari kemudian) mendapat variasi $\left( \pm 20,9^{\prime \prime} \approx 21^{\prime \prime}\right.$ atau $5,35^{\circ}$ ( 1 bulan $=29$ hari) dan $\pm 22,4^{\prime \prime} \approx 23^{\prime \prime}$ atau $5,75^{\circ}$ ( 1 bulan $=30$ hari).
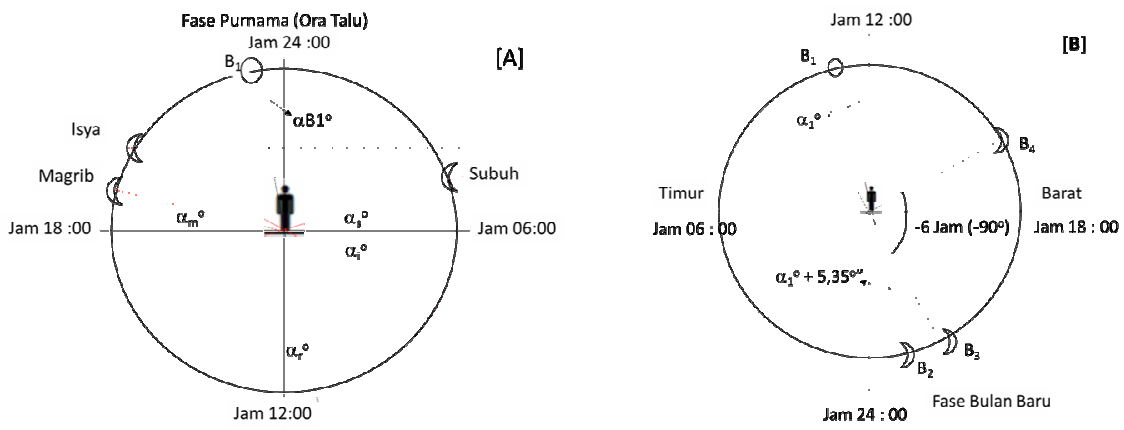

Gambar 6.

Ilustrasi penentuan tinggi Bulan (sudut) untuk jam pengamatan tertentu terhadap referensi waktu lokal dalam Metode Joguru

Posisi Bulan di $\mathrm{B}_{3}$ akan membentuk sudut yang lebih besar $\left(\alpha 1+5,35^{\circ}\right)$ terhadap waktu ikat di jam 12:00 LT (Gambar 6B). Mempertimbangkan bahwa hilal terjadi sebelum shalat Maghrib ( $\approx$ jam 18:00 LT) dan waktu pemantauan Bulan di fase purnama pada saat puncak bulan baru (jam 24:00 LT), maka posisi Bulan diproyeksikan kembali sejauh $90^{\circ}(\approx-6$ jam $)$ dari posisi $B_{3}$ dan menghasilkan posisi Bulan berada pada posisi $\mathrm{B}_{4}$ (Gambar 6B). Posisi terakhir Bulan ( $\left.\mathrm{B}_{4}\right)$ merupakan posisi Bulan saat awal bulan Hijriah (H-1), dimana waktu pemantuan tergantung pada besarnya sudut $\alpha_{1}$. Ilustrasi penentuan waktu pemantauan pada Gambar 6 serupa dengan penerapan MJ yang yang diuraikan pada Gambar 5B. 


\section{Titik Temu Faktor Syar'i dari Metode Joguru}

Faktor penting dalam hisab rukyat awal bulan Hijriah (Ramadhan dan Syawal) jika terdapat 3 titik temu yakni titik temu aspek syar'i, aspek hilal dan aspek atmosfer ${ }^{33}$. Titik temu aspek syar'i dari MJ sebagai bagian kajian kebenaran agamis, bahwa tidak dijumpai dalil (firman dan hadist) yang menjelaskan bahwa awal bulan Hijriah ditentukan dengan pemantauan pergerakan air pada akebai. Tidak adanya dalil yang tegas tersebut diakibatkan pada penerjemahan dan pemaknaan dari QS al-Baqarah [2]:189 (dalil utama) tentang penggunaan kata "hilal". Dalil lainnya merupakan penjelasan tentang proses pergerakan benda angkasa. Pemaknaan hilal umumnya diartikan sebagai Bulan sabit tipis (first new cresent) ${ }^{34}$ saat ijtimak sebagaimana yang didefinisikan oleh Suhardiman ${ }^{35}$ dan masih banyak peneliti/ilmuan lainnya (peneliti dalam maupun luar negeri) yang terfokus pada tanda astronomi.

Tafsir al-Jalalain ${ }^{36}$ untuk QS. al-Baqarah [2]: 189 menjelaskan kata "ahillah" sebagai bentuk jamak dari Hilal, sedangkan dalam Tafsir al-Misbah ${ }^{37}$ menjelaskan "asbābun nuzūl" (sebab turunnya ayat) akibat pertanyaan sahabat Rasul tentang bentuk-bentuk Bulan dalam satu periode tertentu. Dua hal tersebut, maka kata "ahillah" dapat diartikan sebagai proses perjalanan Bulan yang memberi informasi waktu, dimana fase Bulan menjadi indikator umur pergerakan Bulan, sedangkan hilal (makna tunggal) adalah posisi dan ukuran Bulan pada pada waktu tertentu (pertama) dengan munculnya Bulan

\footnotetext{
33Lihat T. Djamaluddin, "Faktor Penting dalam Penentuan Kriteria Hisab Rukyat (Handout)", 2009.

${ }^{34}$ Lihat juga definisi hilal yang dipaparkan oleh S. Azhari, "Penyatuan Kalender Islam: Mendialogkan Wujūd al-Hilāl dan Visibilitas Hilal", dalam Jurnal Ahkam, Vol. XIII No. 2, 2013.

${ }^{35}$ S. Suhardiman, "Kriteria Visibilitas Hilal dalam Penetapan Awal Bulan Qamariah di Indonesia", dalam Khatulistiwa, Vol. 3, 2013, h. 2, S. Siddiq, "Studi Visibilitas Hilal dalam Periode 10 Tahun Hijriyah Pertama (0622 - 0632 CE) Sebagai Kriteria Baru Untuk Penetapan Awal Bulan-Bulan Islam Hijriyah", dalam Prosiding Seminar Nasional Hilal. Lembang, Jawa Barat-19 Desember 2009/2 Muharram 1431 H., Kelompok Keilmuan Astronomi dan Observatorium Bosscha, FMIPA-ITB, Observatorium Bosscha, FMIPA-ITB, 2009, hlm 3-26, lihat juga Y. Dinata, "Rumus dan Parameter Variabel Fase Hilal Awal Bulan Penentu Garis Tanggal Kalender Hijriah Internasional", dalam Proceding International Conference on Qur'anic Studies Centre of Qur'anic Studies (PSQ), Jakarta, 15 -16 Februari 2014, S. Azhari, Perkembangan Kajian Astronomi Islam di Alam Melayu, Journal of Fiqh. 7, 2010, h. 167 - 184

${ }^{36}$ Lihat Tafsir Jalalain surat Al-Baqarah ayat 189 pada http://tafsirq.com/2-al-baqarah/ayat189\#tafsir-jalalayn [Dikunjungi 24 Mei 2016].

37Lihat Tafsir al-Mishbah, QS. al-Baqarah Ayat 189-191. Jakarta: https://www.youtube.com/ watch?v=DNqVY8CtcrU. [Dikunjungi 8 Januari 2014].
} 
sabit tipis (first new cresent) sebagai tanda (indikator) bahwa telah terjadi ijtimak awal bulan baru Hijriah. Kata hilal sendiri menurut kamus Kamus alMunawir ${ }^{38}$ menjelaskan makna dari kata "hilal" dalam 12 makna yakni (1) Bulan sabit, (2) cap, selar pada unta, (3) Bulan yang terlihat pada awal bulan, (4) unta yang kurus, (5) curah hujan, (6) kulit kelongsong ular, (7) permulaan hujan, (8) debu, (9) air sedikit ${ }^{39}$, (10) ular jantan, (11) warna putih pada pangkal kuku, dan (12) anak muda yang bagus.

Pertimbangan aspek syar'i dari Metode Joguru dapat dilihat juga dari pemaknaan hadis Șaḥīh al-Bukhārī No. 1906; Șaḥīh al-Bukhārī, hadis No. 1909; hadis Șahīh Muslim (1080)-03 dan hadis Șahīh Muslim (1081)- 17 tentang pentingnya pemantauan hilal sebagaimana yang termuat dalam Siddiq dan Dinata. ${ }^{40}$ Dalil (hadis) tersebut dapat dimaknai jika suatu tempat yang sebelumnya pernah terlihat Hilal, dan di lain waktu tidak terlihat, maka solusi penentuan bulan baru Hijriah (Ramadhan dan Syawal) dilakukan dengan menambahkan 1 hari (lengkapkan hitungan bulan 30 hari) dan atau menggunakan hasil perhitungan (hisāb 'urfi). Kondisi tidak terlihatnya Hilal di Pulau Tidore dan sekitarnya, maka tidak memungkinkan menjalankan maksud hadis tersebut.

Pemaknaan ahillah tersebut, kata hilal secara astronomi dapat diartikan sebagai tanda hadirnya Bulan sabit tipis (first new cresent) saat konjungsi. Pada bagian lain saat pergerakan Bulan memberikan tanda pada aspek lain salah satunya pada aspek oceanography (pasang surut) sehingga pasang surut juga bermakna ahillah. Alur pikir dalam memaknai kata ahillah tersebut menghasilkan relasi yang harmonis antara ayat-ayat qawliyah dengan ayat kawni$y a h$ atau antara agama dengan sains. ${ }^{41}$ Kesesuaian faktor syar'i lainnya dari MJ

\footnotetext{
${ }^{38}$ Lihat S. Azhari "Penyatuan Kalender Islam: Mendialogkan Wujūd al-Hilāl dan Visibilitas Hilal", dalam Jurnal Ahkam, Vol. XIII No. 2, 2013, h. 159.

${ }^{39}$ Makna kata hilal sebagai "air yang sedikit", secara logis berarti pada lokasi terdapatnya air tersebut, sebelumnya/pernah terdapat air yang banyak, dimana variasi banyak dan sedikitnya terjadi secara periodik dan alami (hilal terjadi secara periodik tiap awal bulan). Fenomena tersebut hanya diperlihatkan pada ritmik pergerakan pasang surut.

${ }^{40}$ S. Siddiq, "Studi Visibilitas Hilal dalam Periode 10 Tahun Hijriyah Pertama (0622 - 0632 CE) sebagai Kriteria Baru Untuk Penetapan Awal Bulan-Bulan Islam Hijriyah", 2009 dan Y. Dinata, "Rumus dan Parameter Variabel Fase Hilal Awal Bulan Penentu Garis Tanggal Kalender Hijriah Internasional", 2014.

41M. Maskufa, "Ilmu Falak : Relasi Harmonis Antara Agama dan Sains", dalam Jurnal Akademika, Vol. 18, 2013, h. 1, dan PH. Rusmin, Harsoyo A, Supriatna A, Rohman AS, "Validasi Atas Dua Pemahaman Kata Ahillah dalam Surah al-Baqarah/2: 189", Musyawarah Kerja Nasional Ulama alQur'an, Serang, 2013, h. 21-24.
} 
diperlihatkan pula pada penerjemahan QS al-Insyiqaq ayat 18 yang terjemahannya "dan demi bulan jika purnama", dimana penentuan waktu pemantauan (hari dan jam) merujuk pada posisi Bulan saat fase purnama (Nishfu Sya'ban dan Nuzulul Qur'an). Secara keseluruhan MJ menerapkan prinsip utama makna yang terkandung pada al-Qur'an dan hadis tentang waktu ibadah sebagai suatu "bayangan" dengan makna umum sebagai tanda dalam suatu proyeksi dari kondisi astronomi dari pola pergerakan sumber cahaya (Matahari dan Bulan) terhadap Bumi.
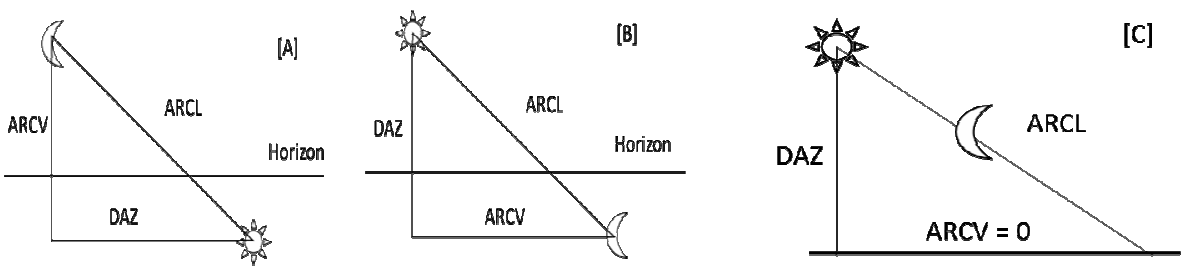

Keterangan:

[A] Geometrik dasar pendekatan Bulan terbit atau metode pemantauan Hilal yang umum saat ini dengan indikator awal bulan baru pada ketampakan Bulan sabit tipis; [B] Geometrik dasar pendekatan Matahari terbenam dari Metode Joguru dengan indikator awal bulan baru pada waktu terjadinya titik balik pergerakan pasang surut (slackwater) pergerakan pasang surut, dan [C] .Bangun geometri dari MJ (lihat uraian gambar 5B),

\section{Gambar 7.}

\section{Geometrik dasar indikator awal bulan baru Hijriah dengan Metode Joguru}

Mempertimbangkan kondisi Kesultanan Tidore saat itu (periode 800 tahun yang lalu), maka dinilai wajar untuk membangun suatu pendekatan logis dalam menentukan awal bulan Ramadhan dan Syawal dengan MJ, maka pendekatan teknis adalah suatu "ijtihad" oleh Joguru Kesultanan Tidore dalam mengatasi permasalahan yang disyariatkan dalam penentuan awal bulan Ramadhan dan Syawal. Ijtihad adalah upaya menyelesaikan persolan yang tidak dibahas secara jelas dalam dalil-dalil tentang penentuan awal bulan Ramadhan dan Syawal. ${ }^{42}$

${ }^{42}$ A. Nuruddin bin Khattab IU, Studi tentang Perubahan Hukum dalam Islam (Jakarta: Rajawali Pers, 1987).

124 || Volume 27, Nomor 1, April 2017

AL-AHKAM

p-ISSN: 0854-4603; e-ISSN: 2502-3209 


\section{Bangun Geometri Dasar Indikator Awal Bulan Baru Hijriah}

Metode pemantauan Hilal saat ini umumnya dilakukan dengan mengamati pergerakan Bulan yang akan terbit, sedangkan MJ dilakukan pendekatan pergerakan Matahari yang akan tenggelam (Gambar 7). Kedua gambar pada menunjukkan komponen parameter yang sama dalam penyusun geometrik dasar ketampakan Hilal ${ }^{43}$ yang meliputi nilai Arc of Light (ARCL), sebagai elongation, yaitu sudut-pisah antara titik pusat-Matahari dan pusat-Bulan DAZ (Delta Azimuth, Relatif Azimuth), yaitu selisih (sudut) azimuth antara Matahari dan Bulan, dan nilai Arc of Vision (ARCV), yaitu selisih (besaran) sudut dalam altitude arah vertikal antara titik pusat Matahari dan titik pusat Bulan. Nilai ARCV inilah yang sering disebut dengan tinggi Bulan (sudut) yang menjadi nilai yang sering dipermasalahkan saat sidang isbat dilakukan.

Tahapan MJ memberi gambaran bangun geometrik sebagaimana (Gambar 7B). Perbedaan mendasar pada dua bangun geometrik tersebut terdapat pada objek yang menjadi referensi ketinggian (sudut). Gambar 7A, referensi tinggi objek merujuk pada objek Bulan dengan nilai ARCV, sedangkan pada Gambar 7B merujuk pada posisi Matahari dengan nilai DAZ. Kedua gambar dengan objek referensi yang berbeda, keduanya menggambarkan posisi Bulan, Bumi dan Matahari pada satu garis lurus (ijtimak). Pada referensi Bulan, indikator kondisi ijtimak diperlihatkan dengan kehadiran Bulan sabit tipis (hilal), sedangkan pada referensi Matahari salah satu indikatornya adalah waktu terjadinya perubahan tinggi air di akebai (M)). Nilai parameter ketampakan Hilal (DAZ) pada MJ diterjemahkan pada panjang bayangan terhadap arah datangnya sinar Matahari, sedangkan nilai ARCL diterjemahkan dalam panjang bayangan yang memotong garis khayal Timur dan Barat (horisontal), panjang bayangan tepat berada memotong pusat lingkaran akebai (Gambar 5B).

Secara umum, kedua bangun geometrik tersebut dibangun berdasarkan waktu terjadinya ijtimak diantara shalat Ashar dan Magrib sebagai waktu akhir (hari) dari penanggalan Hijriah. Posisi Bulan terhadap Matahari dan Bumi memberikan efek bayangan ke Bulan dalam bentuk Bulan sabit tipis menjelang terbenam Matahari. Hal ini menyebabkan Bulan harus berada di atas ufuk (garis

\footnotetext{
43S. Siddiq, "Studi Visibilitas Hilal dalam Periode 10 Tahun Hijriyah Pertama (0622 - 0632 CE) sebagai Kriteria Baru Untuk Penetapan Awal Bulan-Bulan Islam Hijriyah", dalam Prosiding Seminar Nasional Hilal. Lembang, Jawa Barat-19 Desember 2009, h. 3-26.
} 
horizon) agar cahaya Matahari sampai ke Bulan dan terlihat oleh pemantau di Bumi. Keterlambatan Bulan terbenam (moonset) di awal fase bulan baru pada MJ adalah kondisi ijtimak (Gambar 7B) yang merujuk pada posisi Matahari.

\section{Ethnooceanography dalam Metode Joguru}

Pola pergerakan pasang surut sangat dipengaruhi oleh pergerakan benda langit terutama Bulan dan Matahari ${ }^{44}$, pengaruh Bulan dominan membentuk ritmik tinggi air yang konsisten berdasarkan penanggalan $\mathrm{Hijriah}^{45}$. Konsistensi pergerakan tinggi air tersebut menyebabkan Suku Sama (Orang Bajo) melakukan perhitungan tunggang air untuk kegiatan konstruksi rumah maupun sero tancap (fish trap) dengan melakukan pengukuran saat bulan Sya'ban. ${ }^{46}$. Pola pikir dan tindakan suku sama tersebut merupakan Ethno-Oceanography. ${ }^{47}$

Pergerakan air di akebai merupakan pergerakan yang dipicu oleh pergerakan pasang surut, dimana saat air bergerak surut maka tinggi air (kedalaman air) pada akebai akan berkurang dan demikian pula sebaliknya. Perubahan tinggi air diakibatkan oleh sistem aquifera lokasi akebai didominasi oleh pantai batu berpasir, dimana $C^{4} n^{48}$ menyatakan bahwa ukuran material pantai berbatu lebih cepat memberi pengaruh naiknya permukaan air atau perembesan air laut dibandingkan dengan material berpasir.

Pendekatan yang dilakukan oleh Joguru Kesultanan Tidore dalam mengamati perubahan tinggi air pada akebai adalah memindahkan pergerakan 1996.

${ }^{44}$ DT. Pugh, Tides, Surges and Mean Sea-Level (Reprinted With Corrections), John Wiley \& Sons Ltd,

45Salnuddin, Nurjaya; IW, Jaya; I, Natih; NM. "Variasi Amplitudo Konstituen Harmonik Pasang Surut Utama di Stasiun Bitung, dalam Ilmu Kelautan”, Indonesian Journal of Marine Sciences. Vol. 20, 2015, h. 73 - 86.

${ }^{46}$ Salnuddin, Nurjaya; IW, Jaya; I, Natih; NM., "Perhitungan Tunggang Air Pasang Surut Berdasarkan Kearifan Lokal Masyarakat Suku Sama di Wilayah Timur Indonesia”, dalam Jurnal Ilmu dan Teknologi Kelautan Tropis, Vol. 7, 2015, h. 347-363.

47MA. Gasalla, Diegues AC,. People's Seas:"Ethnooceanography" as an Interdisciplinary Means to Approach Marine Ecosystem Change, World Fisheries: A Social-Ecological Analysis, Wiley-Blackwell, Oxford, UK, 2011, h. 120-136. Gasalla mendefinisikan ethnooceanography sebagai suatu kajian kemasyarakatan (ethno) tentang fenomena lingkungan dan interaksi masyarakat dengan kehidupan makhluk hidup atau cara masyarakat berinteraksi dengan lingkungan laut.

48Y. Chen, Chen G, Yeh H, Jeng D, "Estimations of Tidal Characteristics And Aquifer Parameters Via Tide-Induced Head Changes in Coastal Observation Wells," dalam Hydrology and Earth System Sciences Discussions, 7(6), 2010, h. 9155-9171. 
(ritmik) pasang surut dalam suatu ruang terkontrol tanpa pengaruh angin yang memicu bangkitnya gelombang. Dengan meminimalisir pengaruh gelombang maka pergerakan air pada akebai adalah relatif berasal dari pergerakan pasang surut. Memperhatikan gaya Pembangkit Pasang Surut (GPP) sebagai gradient jarak Bulan dan Matahari terhadap Bumi, maka tinggi air pada bulan Hijriah tertentu senantiasa membentuk ritmik tinggi air tertentu pula. Perubahan gradient jarak yang dicermati oleh Suku Sama melahirkan metode perhitungan tungang air yang efektif, dimana jumlah data pengukuran terdiri dari 2 jam pengukuran.$^{49}$ Prinsip yang sama dengan suku Bajo, para Joguru mengamati Akebai dalam menentukan awal bulan Ramadhan dan Syawal pada prinsipnya melakukan pengamatan pergerakan pasang surut (etnooceanography).

Pergerakan Bulan dalam mengelilingi Bumi menginformasikan waktu penanggalan Hijriah (lunar calender) dan juga menyebabkan perubahan tinggi muka air pasang surut. Perubahan tersebut diperlihatkan pada kondisi air pasang maksimum terjadi saat fase bulan baru dan fase purnama, sedangkan pada fase kuartil tinggi air minimum. Saat fase bulan baru (konjungsi), posisi Bulan-Bumi-Matahari secara astronomi berada pada satu garis lurus melalui inti Bumi, pada kedua tersebut GPP maksimum dan permukaan Bumi terjadi pasang (bulge), sedangkan pada wilayah berada pada sisi $90^{\circ}$ dari garis potong tersebut pada kondisi surut, kondisi tersebut merupaskan suatu keseimbangan (teori equibilirium) pergerakan pasang surut.50

Penentuan awal bulan baru Hijriah (astronomy) diawali dengan fenomena ijtimak, yaitu posisi Bulan dan Matahari searah dengan pemantau. ${ }^{51}$ Indikator hilal (first new cresent) akan terlihat setelah terjadinya ijtimak disusul oleh fenomena konjungsi dan membentuk bulges. Hilal secara geometris bukanlah

\footnotetext{
${ }^{49}$ Lihat, Salnuddin; Nurjaya; I. W., Jaya;, I., \& Natih;, N. M “Perhitungan Tunggang Air Pasang Surut Berdasarkan Kearifan Lokal Masyarakat Suku Sama di Wilayah Timur Indonesia".

${ }^{50} \mathrm{~A}$. Love, The Yielding of The Earth to Disturbing Forces, dalam Proceedings of the Royal Society of London Series A. 82, 1909, h. 73-88, P. Vaniček,. The Earth Tides, Department of Surveying Engineering, University of New Brunswick, 1973, CF. Yoder, Williams JG, Parke ME, "Tidal Variations Of Earth Rotation", dalam Journal of Geophysical Research: Solid Earth. 86(B2), 1981, h. 881-891, lihat juga EI. Butikov, "A Dynamical Picture of the Oceanic Tides", dalam American Journal of Physics. 70(10), 2002, h. 1001-1011

51Maskufa, W. Widiana,. "Titik Kritis Penentuan Awal Puasa dan Hari Raya di Indonesia," dalam Jurnal AHKAM, 12, 2012, h. 1, dan M. Maskufa, 'Ilmu Falak : Relasi Harmonis Antara Agama dan Sains,' dalam Jurnal Akademika, 18, 2013, h. 1.
} 
posisi Bulan-Bumi-Matahari benar-benar satu garis lurus melalui pusat inti Bumi (konjungsi), namun garis lurus terbentuk dengan posisi pemantau berada di permukaan Bumi sehingga dapat melihat cahaya Matahari yang sampai ke Bulan dan membentuk Bulan sabit (cresent) yang sebelumnya terhalangnya oleh permukaan Bumi. Posisi pemantau hilal tersebut berarti membentuk sudut yang sama (90 ) dengan Metode Joguru (lihat Gambar 5).

Declinasi Bulan terhadap Bumi bervariasi sekitar $5^{\circ}$ menyebabkan ijtimak senantiasa bervariasi. Variasi ijtimak dan keterlambatan pergerakan Bulan dari rotasi Bumi (synodic) rata-rata berkisar 42-46 menit perbulan saat ijtimak bulan sebelumnya, memungkinkan variasi waktu terjadi ijtimak (air surut) terjadi dalam rentang waktu tersebut. Uraian ini pada prinsipnya sama dengan maksud oleh Ade Don ${ }^{52}$ dan Hi Hasanuddin Malagapi ${ }^{53}$ yang menyatakan bahwa setiap awal bulan baru Hijriah (ijtimak) air laut dalam keadaan surut, dan saat bergerak pasang berarti telah masuk tanggal 1 bulan Hijriah. Kondisi pasang surut yang terpantau pada akebai dari MJ memungkinkan waktu terjadinya titik balik pergerakan surut ke pasang (slackwater) menjadi indikator awal bulan baru Ramadhan dan Syawal, hal tersebut diperlihatkan bahwa saat ijtimak terjadi sebelum konjungsi $( \pm$ 3jam sebelumnya). Waktu dan tipe pasang surut yang berkembang di Tidore bertipe semidiurnal ${ }^{44}$ maka 3 jam sebelumnya air laut dalam kondisi surut.

\section{Kesimpulan}

Metode Joguru perlu untuk dikaji/riset lebih lanjut dan lebih komprehensif dalam upaya determinasi informasi yang terpantau pada akebai (pasang surut) sekaligus untuk replika MJ di lokasi lain. Kesesuaian Ethnooceanography dan titik temu aspek syar'i dari MJ dapat menjadikan sebagai metode utama dalam penentuan awal bulan baru Hijriah yang mampu menentukan waktu terjadinya ijtimak dengan indicator waktu terjadinya slack water, sekaligus sebagai pembanding untuk pemantauan awal bulan dengan indikator astro-

\footnotetext{
${ }^{52}$ Ade don, merupakan dewan adat/Balakusu Sekano-kano Kesultanan Ternate, Diskusi, Juni 2016.

${ }^{5}$ Ibid 3, menjelaskan bahwa saat pemantauan dengan MJ, para Joguru tidak dalam keadaan basah atau dengan kata lain tidak mungkin dapat melakukan pemantauan karena akebai tergenang air laut.

${ }^{54}$ Semidiurnal, pergerakan pasang surut dalam 1 hari terbentuk 2 kali pasang dan 2 kali surut dengan tinggi air pasang (peak) I dan peak II berbeda.
} 
nomi (hilal). Indikator awal bulan baru secara astronomi (first new cresent) merupakan indikator terakhir telah terjadinya ijtimak. Perlu dilakukan perluasan makna kata hilal sebagai indikator alam (tanda-tanda) dalam penentuan waktu awal bulan baru Hijriah dan bukan hanya bermakna sebagai tampaknya Bulan sabit tipis pertama (first new cresent).[a]

\section{DAFTAR PUSTAKA}

Anwar S., "Perkembangan Pemikiran tentang Kalender Islam Internasional", dalam: Musyawarah Ahli Hisab dan Fikih Muhammadiyah, Yogyakarta. 21-22 Jumadis Saniah 1429 H / 25-26 Juni 2008. Yogyakarta.

Azhari S., "Ilmu Falak: Perjumpaan Khazanah Islam dan Sains Modern", Suara Muhammadiyah, 2007.

"Perkembangan Kajian Astronomi Islam di Alam Melayu", dalam Journal of Fiqh. 7, 2010,

"Penyatuan Kalender Islam: Mendialogkan Wujūd al-Hilāl dan Visibilitas Hilal", dalam Jurnal Ahkam, Vol. XIII No. 2, 2013.

Butikov EI., "A Dynamical Picture of The Oceanic Tides", dalam American Journal of Physics, Vol. 70 No. 10, 2002.

Chen Y, Chen G, Yeh H, Jeng D., "Estimations of Tidal Characteristics And Aquifer Parameters Via Tide-Induced Head Changes in Coastal Observation Wells", dalam Hydrology and Earth System Sciences Discussions, Vol. 7 No. 6, 2010.

Dinata Y., Rumus dan Parameter Variabel Fase Hilal Awal Bulan Penentu Garis Tanggal Kalender Hijriah Internasional, dalam Proceding International Conference on Qur'anic Studies Centre of Qur'anic Studies (PSQ), Jakarta, 15-16 Februari, 2014.

Djamaluddin T., "Faktor Penting Dalam Penentuan Kriteria Hisab Rukyat (Handout)", dalam Prosiding Seminar Nasional Hilal. Lembang - Jawa Barat-19 Desember 2009/2 Muharram 1431 H, Kelompok Keilmuan Astronomi dan Observatorium Bosscha, FMIPA-ITB, Observatorium Bosscha, FMIPA-ITB, 2009.

Djamaluddin T., "Visibilitas Hilal di Indonesia", Warta LAPAN, Vol. 2, 2010.

Gasalla MA, Diegues AC, "People's Seas: "Ethnooceanography" As An Interdisciplinary Means to Approach Marine Ecosystem Change", dalam World Fisheries: A Social-Ecological Analysis, Wiley-Blackwell, Oxford, UK, 2011. 
Salnuddin, et.al

Izzuddin A., "Dinamika Hisab Rukyat di Indonesia", dalam Istinbath Jurnal Hukum, Vol. 12, 2015.

Jannah S., "Urgensi Hisab dan Rukyat Pasca UU No. 3 Tahun 2006", dalam Jurnal Al-Mawarid (Jurnal Hukum Islam), 2007.

Kementerian Agama Republik Indonesia, Ilmu Falak Praktik, Jakarta:, Sub Direktorat Pembinaan Syari'ah dan Hisab Rukyat, Direktorat Urusan Agama Islam \& Pembinaan Syari'ah, Direktorat Jenderal Bimbingan Masyarakat Islam, Kementerian Agama Republik Indonesia, Cet. I, November 2013.

Love A., "The Yielding of the Earth to Disturbing Forces" dalam Proceedings of the Royal Society of London, Series A. 82, 1909.

Marasabessy B., "Tuan Guru: The Cap Muslim Muslim Phylosophy Education System", MAKARA of Social Sciences and Humanities, Series. 8, 2010.

Maskufa, Widiana W., "Titik Kritis Penentuan Awal Puasa dan Hari Raya di Indonesia", Jurnal AHKAM, 12, 2012.

Maskufa M., "Ilmu Falak: Relasi Harmonis Antara Agama dan Sains", dalam Jurnal Akademika, Vol. 18, 2013.

Nashirudin M., "Tinjauan Fikih dan Astronomis Penyatuan Matlak", dalam Ijtihad: Jurnal Wacana Hukum Islam dan Kemanusiaan, Vol. 12, 2012.

Nuruddin A, bin Khattab IU., Studi tentang Perubahan Hukum dalam Islam, Jakarta: Rajawali Pers, 1987.

Odeh M, Accurate Times 5.3.6 Software, Islamic Crescents' Observation Project (ICOP), 2013.

Probojo L., Ritual Guardians Versus Civil Servants As Cultural Brokers In The New Order Era: Local Islam In Tidore, North Maluku 1, dalam Indonesia and the Malay World, Vol. 38 No. 110, 2010.

Pugh DT., Tides, Surges and Mean Sea-Level, (reprinted with corrections), John Wiley \& Sons Ltd., 1996.

Rusmin PH, Harsoyo A, Supriatna A, Rohman AS., "Validasi Atas Dua Pemahaman Kata Ahillah dalam Surah al-Baqarah [2]: 189", dalam Musyawarah Kerja Nasional Ulama Al-Qur'an, Serang, 2013.

Salimi M., "Visibilitas Hilal Minimum: Studi Komparatif antara Kriteria Depag RI dan Astronomi", 2005.

Salnuddin, Nurjaya; IW, Jaya; I, Natih; NM., "Perhitungan Tunggang Air Pasang Surut Berdasarkan Kearifan Lokal Masyarakat Suku Sama di Wilayah

130 || Volume 27, Nomor 1, April 2017 
Timur Indonesia", dalam Jurnal Ilmu dan Teknologi Kelautan Tropis, Vol. 7,2015.

"Variasi Amplitudo Konstituen Harmonik Pasang Surut Utama di Stasiun Bitung", dalam Ilmu Kelautan, Indonesian Journal of Marine Sciences, Vol. 20, 2015.

Siddiq S., "Studi Visibilitas Hilal Dalam Periode 10 Tahun Hijriyah Pertama (0622 - 0632 CE) Sebagai Kriteria Baru Untuk Penetapan Awal BulanBulan Islam Hijriyah", dalam Prosiding Seminar Nasional Hilal. Lembang - Jawa Barat-19 Desember 2009/2 Muharram 1431 H, Kelompok Keilmuan Astronomi dan Observatorium Bosscha, FMIPA-ITB, Observatorium Bosscha, FMIPA-ITB, 2009.

Suhardiman S., "Kriteria Visibilitas Hilal dalam Penetapan Awal Bulan Kamariah di Indonesia", dalam Khatulistiwa, Vol. 3, 2013.

Vaniček P., The Earth Tides, Department of Surveying Engineering, University of New Brunswick, 1973.

Widyantoro BT., "Karakteristik Pasang Surut Laut di Indonesia", dalam Jurnal Ilmiah Geomatika, Vol. 20 No. 1, 2014.

Yallop BD., "A Method for Predicting the First Sighting of the New Crescent Moon", dalam NAO Technical Note, 1997.

Yoder CF, Williams JG, Parke ME., Tidal Variations of Earth Rotation, dalam Journal of Geophysical Research: Solid Eart, Vol. 86 (B2), 1981. 
132 || Volume 27, Nomor 1, April 2017 